\title{
2,6-Dicyanoaniline based donor-acceptor compounds: the facile synthesis of fluorescent 3,5-diaryl/hetaryl-2,6-dicyanoanilines
}

\author{
Ergin Yalçına, Yasemin Cemile Kutlua ${ }^{a}$, Vildan Korkmaz ${ }^{a}$, Ertan Şahin $^{b}$ \\ and Zeynel Seferoğlu ${ }^{\mathbf{a}^{*}}$ \\ ${ }^{a}$ Department of Chemistry, Faculty of Science, Gazi University, Teknikokullar, Ankara 06500, \\ Turkey \\ ${ }^{b}$ Atatürk University, Department of Chemistry, Erzurum, 25240,Turkey \\ E-mail: znseferoglu@gazi.edu.tr
}

DOI: http://dx.doi.org/10.3998/ark.5550190.p009.102

\begin{abstract}
A series of new 3,5-diaryl/hetaryl-2,6-dicyanoaniline derivatives were synthesized by threecomponent one-pot procedure at room temperature to $80{ }^{\circ} \mathrm{C}$. The experimental procedure in the preparation of the target compounds is simple, reproducible and it includes short reaction times and easy-isolation/purification of the products. The synthesized compounds are fluorescent active and show wavelength of maximum absorption $\left(\lambda_{\max }\right)$ in UV or visible region in DMSO at room temperature.
\end{abstract}

Keywords: 3,5-Diaryl/hetaryl-2,6-dicyanoanilines, coumarin, three-component one-pot procedure, donor-acceptor, aniline derivatives

\section{Introduction}

Organic dyes which include donor-acceptor groups exhibit different optical and photophysical characteristics. ${ }^{1}$ Substituted 2,6-dicyanoanilines are typical donor-acceptor compounds and have various potent application fields because of their strong fluorescent properties. ${ }^{2}$ They include one donor group $\left(\mathrm{NH}_{2}\right)$, two acceptor groups $(\mathrm{CN})$. Thus, they have been named as Acceptor-DonorAcceptor (A-D-A) system. Recently, the 2,6-dicyanoanilines and related A-D-A systems have been studied widely for their structural features, optical properties, and various biological activities. ${ }^{3}$ In addition, the 2,6-dicyanoanilines type of A-D-A system constitutes a part of the molecular framework of many biological important compounds such as quinolines, isoquinolines, tetrahydroisoquinolines, fluorenes, 9-oxofluorenes, benzofurans, naphthalenes, steroids, quinazolines, phenoxazines and coumarins. ${ }^{4-17}$ 
The most studied derivatives of 2,6-dicyanoanilines are 3,5-disubstituted-2,6dicyanoanilines, and many synthetic procedures and catalyst systems have been used in the synthesis of 3,5-disubstituted-2,6-dicyanoanilines. ${ }^{3}$ They are generally obtained from one-pot reaction process via multicomponent domino coupling reaction pathway by using appropriate aldehyde and ketone. Conventionally, the syntheses of 3,5-disubstituted-2,6-dicyanoanilines are catalyzed by a basic catalyst such as piperidine. ${ }^{18,19}$ Many other homogeneous and heterogeneous catalysts instead of piperidine were also employed for this coupling, including $\mathrm{NaOH}$, solvent free molten $\mathrm{K}_{2} \mathrm{CO}_{3}$, ethanediamine, $\mathrm{NaOH} / \mathrm{ZnTiO}_{3}$ and $\mathrm{KF} /$ Alumina ${ }^{20-23}$. Moreover, they were also prepared under microwave irradiation and by different methods of grinding. ${ }^{24,25}$

Although various synthetic procedures for the synthesis of 3,5-diaryl/hetaryl-2,6dicyanoanilines have been reported, but they need too long reaction times and they have relatively low yields. Additionally, some of them have no reproducibility and have harsh reaction conditions. Others are also toxic, and expensive catalysts are used in these synthetic processes.

Because of the above requirements, a more general, reproducible, efficient, and viable route for the synthesis of functionalized 3,5-diaryl/hetaryl-2,6-dicyanoanilines is highly desirable. Here, we report a facile three-component one-pot synthetic route toward new fluorescent 3,5diaryl/hetaryl-2,6-dicyanoanilines via multicomponent domino reaction pathways with moderate, to good yield. In optimized reaction, piperidine was used as base and the reactions were carried out at room temperature to $80{ }^{\circ} \mathrm{C}$ in acetonitrile.

\section{Results and Discussion}

For the initial experiment, we explored the optimum reaction condition for the synthesis of 2,6dicyano-3,5-di(2-thienyl)aniline (1) by using 2-(1-(thiophen-2-yl)ethylidene)malononitrile (1.0 equiv.) (1a) with 2-thiophenecarboxyaldehyde (1.0 equiv.)/2-(2-thienylmethylene)malononitrile (1.0 equiv.) (1d) and malononitrile (1.0 equiv.) as model substrates. Generally, piperidine is the most useful organic base in this type of three-component reactions. Thus, we chose piperidine as catalyst. The effect of different catalysts, solvent and temperature conditions on the model reaction were also examined. Without any base, both reaction (See supplementary data; Reaction type 1, Scheme S1, Tables S1-S3) did not take place at all even after 24 hours of reflux, and the starting materials remained completely unconsumed.

In the first pathway (Reaction type 1), 2-thiophenecarboxyaldehyde was used as free aldehyde while in the second pathway (Reaction type 2), 2-(2-thienylmethylene)malononitrile (1d) was used as protected aldehyde, in which higher product yields were obtained. The results are listed in tables S1-S3 (See supplementary data). In this reaction conditions, many different side reactions such as competitive cannizzaro reaction can appear when 2thiophenecarboxyaldehyde is used. ${ }^{23}$ Therefore, the use of $\mathbf{1 d}$ is more convenient (Reaction type 2). For both reaction type, piperidine was used as catalyst. In the case of acetonitrile as a solvent, 
the reaction was very fast, clean, and gave a maximum yield in a short time at room temperature to $80{ }^{\circ} \mathrm{C}$ (Scheme 1$)$.

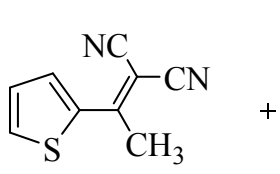

1a<smiles>N#CC(C#N)=Cc1cccs1</smiles>

1d

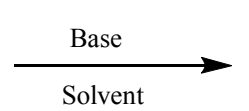<smiles>N#Cc1c(-c2cccs2)cc(-c2cccs2)c(C#N)c1N</smiles>

Scheme 1. Synthetic pathway for second reaction type.

After finding the appropriate solvent, we next focused on optimizing of kind and amount of catalyst. Some readily available and commonly used organic bases such as triethylamine (TEA), pyridine, $N, N$-dimethyl-4-aminopyridine (DMAP), pyrrolidine, diethylamine (DEA), morpholine and piperidine were used separately to optimize kind of base. Pyridine did not trigger both reaction, while the other organic bases catalyzed the reaction to furnish the desired model compound (1), albeit in lower yield than piperidine. So, the best reaction condition for compound 1 was found to be following; the base is piperidine, the solvent is acetonitrile and the reaction finished after 10 minutes at room temperature with (1a) and (1d). Also, it was found that one equivalent of piperidine provided the best result (Table 1). A smaller amount of piperidine $(0.1$ equiv.) in the reaction reduced the yield by $8 \%$ even after increasing the reaction time and temperature significantly.

Table 1. Optimization of solvent, temperature and time by using different amount of piperidine for the synthesis of $\mathbf{1}$ via Reaction type 2

\begin{tabular}{lllll}
\hline Solvents & Piperidine & Temp. $\left({ }^{\mathrm{O}} \mathrm{C}\right)$ & Time & Yields $(\%)$ \\
\hline Acetonitrile & cat. & $\mathrm{rt}$ & $10 \mathrm{~min}$. & 60 \\
Acetonitrile & equiv. & $\boldsymbol{r t}$ & $\mathbf{1 0 ~ m i n .}$ & $\mathbf{6 8}$ \\
Acetonitrile & cat. & 80 & $18 \mathrm{~h}$ & 54 \\
Acetonitrile & equiv. & 80 & $18 \mathrm{~h}$ & 47 \\
Ethanol & cat. & $\mathrm{rt}$ & $10 \mathrm{~min}$. & 41 \\
Ethanol & equiv. & $\mathrm{rt}$ & $10 \mathrm{~min}$. & 11 \\
Ethanol & cat. & 80 & $18 \mathrm{~h}$ & 41 \\
Ethanol & equiv. & 80 & $18 \mathrm{~h}$ & 44 \\
Methanol & equiv. & $\mathrm{rt}$ & $10 \mathrm{~min}$. & 47 \\
Methanol & equiv. & 80 & $18 \mathrm{~h}$ & 28 \\
Toluene & equiv. & $\mathrm{rt}$ & $10 \mathrm{~min}$. & 18 \\
Toluene & equiv. & 80 & $18 \mathrm{~h}$ & 47 \\
DMF & equiv. & $\mathrm{rt}$ & $10 \mathrm{~min}$. & 51 \\
DMF & equiv. & 80 & $18 \mathrm{~h}$ & 47 \\
\hline
\end{tabular}

rt:Room temperature, min.: Minute, h:Hour 
After optimization and finding the best conditions for compound 1, we synthesized new 3,5disubstituted-2,6-dicyanoanilines under the optimized conditions (Scheme 2).

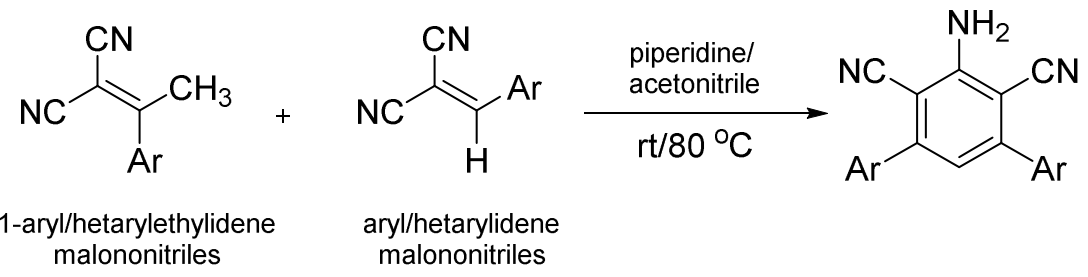

Scheme 2. Synthesis of 3,5-disubstituted 2,6-dicyanoanilines (1-13).

As it can be seen from Table 2, 3,5-diaryl/hetaryl-2,6-dicyanoanilines containing (7- $\mathrm{N}, \mathrm{N}$ diethylamino)coumarinyl moiety 6-13 were obtained with better yields than compound $\mathbf{1}$. Additionally, the compounds $\mathbf{2 - 5}$ were obtained at higher temperatures, longer reaction times and lower yields than compound $\mathbf{1}$ (Table 2).

Table 2. Optimized conditions and yields of compounds 1-13

\begin{tabular}{cccccc}
\hline Ar & Ar & Com- & Temp. & Time & Yields \\
& & pounds & $\begin{array}{c}\left.{ }^{\circ} \mathrm{C}\right) \\
(\%)\end{array}$ \\
\hline 2-Thienyl & 2-Thienyl & $\mathbf{1}$ & $\mathrm{rt}$ & $10 \mathrm{~min}$. & 68 \\
4-Aminophenyl & 2-Thienyl & $\mathbf{2}$ & 80 & $18 \mathrm{~h}$ & 48 \\
4-Aminophenyl & 4-Chlorophenyl & $\mathbf{3}$ & 80 & $18 \mathrm{~h}$ & 27 \\
4-Aminophenyl & 4-Nitrophenyl & $\mathbf{4}$ & 80 & $18 \mathrm{~h}$ & 46 \\
4-Aminophenyl & 3-Pyridyl & $\mathbf{5}$ & 80 & $18 \mathrm{~h}$ & 45 \\
3-(7- $N, N$-diethylamino)-coumarinyl & 2-Thienyl & $\mathbf{6}$ & $\mathrm{rt}$ & $2 \mathrm{~h}$ & 80 \\
3-(7- $N, N$-diethylamino)coumarinyl & 2-Furyl & $\mathbf{7}$ & $\mathrm{rt}$ & $2 \mathrm{~h}$ & 60 \\
3-(7- $N, N$-diethylamino)coumarinyl & 4-Chlorophenyl & $\mathbf{8}$ & $\mathrm{rt}$ & $2 \mathrm{~h}$ & 84 \\
3-(7- $N, N$-diethylamino)coumarinyl & 4-Nitrophenyl & $\mathbf{9}$ & $\mathrm{rt}$ & $2 \mathrm{~h}$ & 84 \\
3-(7- $N, N$-diethylamino)coumarinyl & Phenyl & $\mathbf{1 0}$ & $\mathrm{rt}$ & $2 \mathrm{~h}$ & 76 \\
3-(7- $N, N$-diethylamino)coumarinyl & 3-Pyridyl & $\mathbf{1 1}$ & $\mathrm{rt}$ & $2 \mathrm{~h}$ & 83 \\
3-(7- $N, N$-diethylamino)coumarinyl & 4-Methoxyphenyl & $\mathbf{1 2}$ & $\mathrm{rt}$ & $2 \mathrm{~h}$ & 59 \\
3-(7- $N, N$-diethylamino)coumarinyl & 4-Carboxyphenyl & $\mathbf{1 3}$ & $\mathrm{rt}$ & $2 \mathrm{~h}$ & 57 \\
\hline
\end{tabular}

rt:Room temperature, min.: Minute, h:Hour

All the synthesized compounds were fully characterized by their spectra (IR, ${ }^{1} \mathrm{H} /{ }^{13} \mathrm{C}$ NMR and HRMS, See supplementary data), and the molecular structure of $N, N$-diethylamino-3,5-di(2thienyl)-2,6-dicyanoaniline derivative (Compound 1-II) was also confirmed by X-ray diffraction analysis. 
In accordance with the suggested mechanism in our study, first step in the mechanism is believed to be the abstraction of the acidic proton from (1-aryl/hetarylethylidene)malononitrile by the base, followed by Michael addition of the resulting carbanion (I) to arylidene/hetarylidenemalononitriles to generate Michael product II (Scheme 3). Thorpe-Ziegler cyclization occurs in II to obtain III as imine tautomer. There is an amino-imino tautomeric equilibrium between III and IV. In the synthesis of 3,5-disubstituted-2,6-dicyanoanilines, the critical step is elimination of hydrogen cyanide $(\mathrm{HCN})$ with a base, because the target aromatic compound occurs in this step. In the last step of the proposed mechanism, the elimination of HCN from IV with proper base gave the 3,5-disubstituted-2,6-dicyanoanilines.

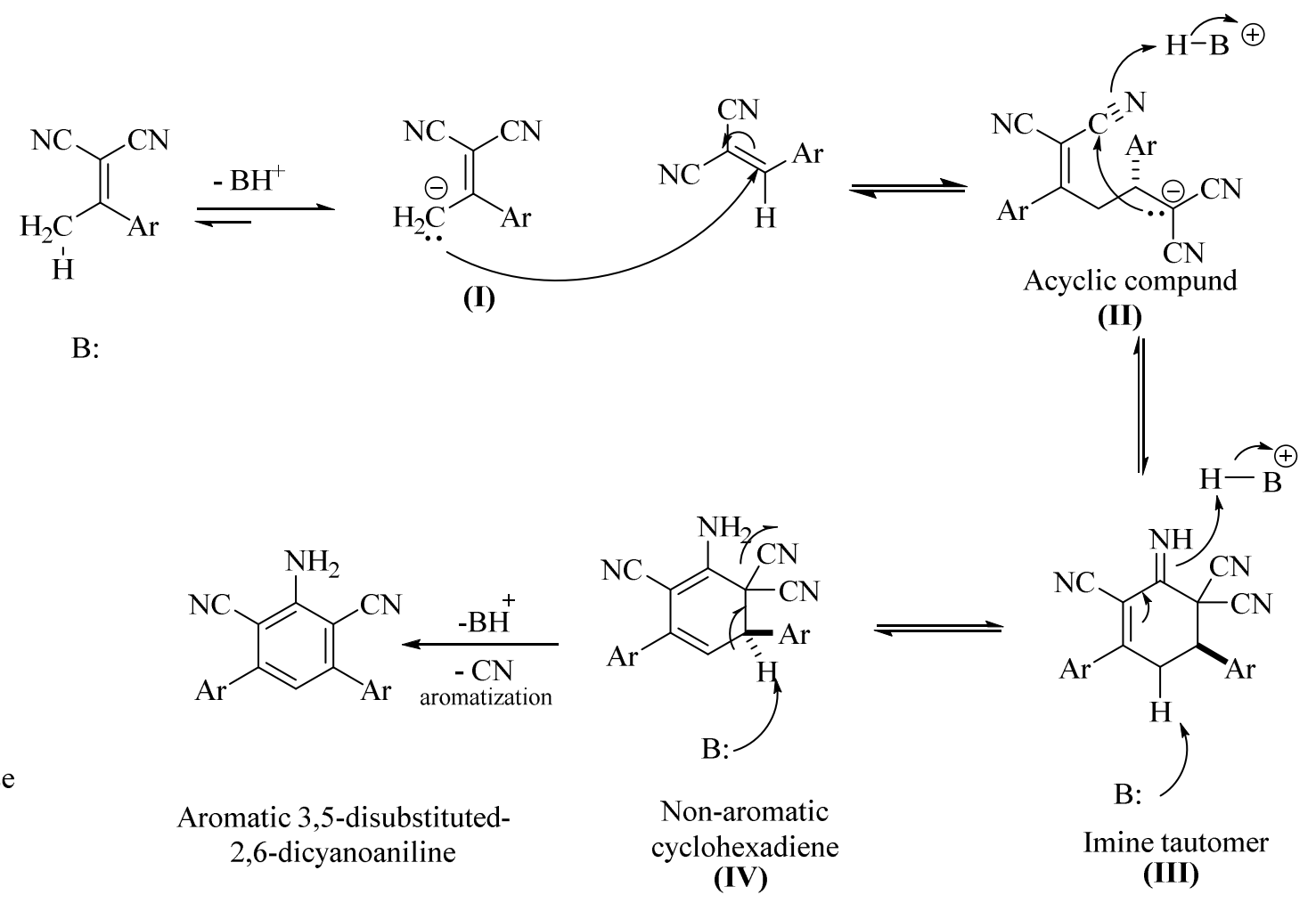

Scheme 3. The proposed mechanism for the formation of 3,5-disubstituted-2,6-dicyanoanilines (1-13).

The electronic properties of the substituents have significant effect on this type of threecomponent reactions. To the best of our knowledge, although many 3,5-disubstituted-2,6dicyanoanilines, including electron-withdrawing groups (such as the halides $(\mathrm{F}, \mathrm{Cl}$ and $\mathrm{Br}$ ) and $\mathrm{NO}_{2}$ ) or electron-donating groups (such as alkyl, alkoxy groups) have been synthesized, until recently only a few examples have been described, including strong electron-donating groups such as amino. ${ }^{17,21}$ In our study, we synthesized 3,5-disubstituted-2,6-dicyanoanilines (2-5) from 2-[1-(4-aminophenyl)ethylidene]malononitrile (1c) bearing strong electron-donating amino 
group. The lowest yield was obtained in this step even at $80{ }^{\circ} \mathrm{C}$. We think that, the amino group complicates the elimination of $\mathrm{HCN}$ in (IV) (Scheme 4) due to the obtained tautomeric structures $\mathbf{V}$ and VI.

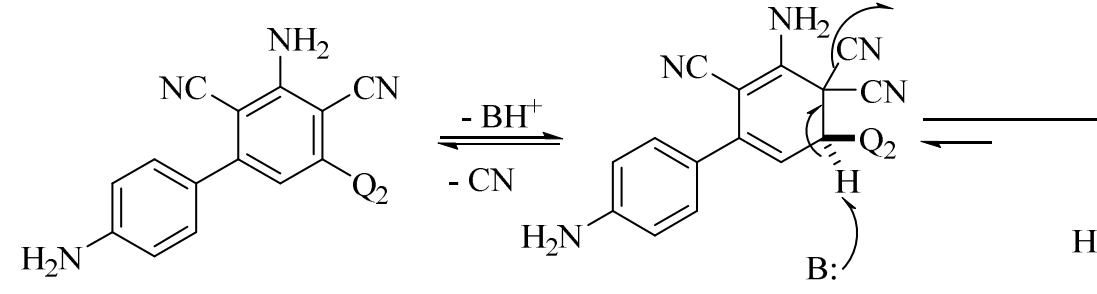

Aromatic 3,5-disubstituted2,6-dicyanoaniline

B: $=$ Base
Non-aromatic cyclohexadiene

(IV)

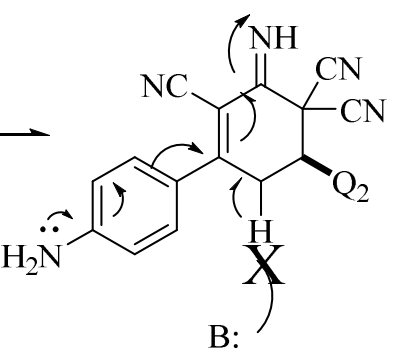

Amino-imino tautomer (V)<smiles></smiles>

(VI)

Scheme 4. The proposed partial restriction of elimination.

In addition, the obtained carbanion (VII) in the first step of the proposed reaction can be unstable because of electron-donating amino group in para position of 1c (Scheme 4 and 5). These results were not observed in 3,5-diaryl/hetaryl-2,6-dicyanoanilines containing (7- $\mathrm{N}, \mathrm{N}$ diethylamino)coumarinyl moiety 6-13, although they have strong electron-donating $N, N$ diethylamino group at 7-position of the coumarin ring.

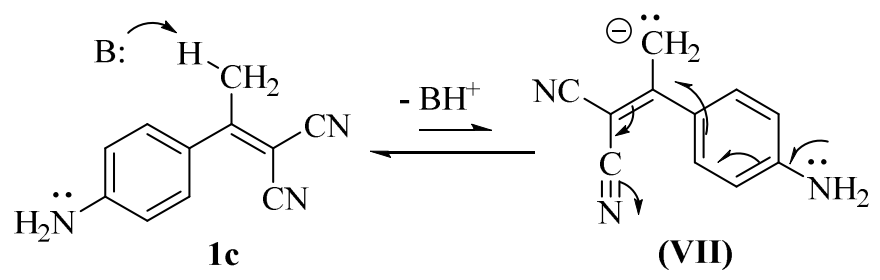

$$
\mathrm{B}:=\text { Base }
$$

Scheme 5. Proposed instability of the carbanion with $+\mathrm{R}$ effect of amino group. 
Alkylamino groups have often been used as organic donor groups in donor-acceptor system. In our study, in order to increase donor properties of model compound, we synthesized, selectively novel mono- and dialkylamino derivatives of 3,5-di(2-thienyl)-2,6-dicyanoanilines. They were easily prepared from starting compound $\mathbf{1}$ and alkyl halides by using $\mathrm{NaH}$ as base in freshly distilled THF. $N$-mono and $N, N$-dialkyl compounds (1-I-III) have better solubility than compound $\mathbf{1}$ and they had higher fluorescence intensity and larger Stokes shift than $\mathbf{1}$. In addition, $N$-mono alkyl compound 1-I can be important for obtaining new $N, N$-dialkyl derivatives. The molecular structure of compound 1-II was also determined by X-ray diffraction analysis [Figure 1. (a) and (b)]. It crystallizes in monoclinic $P 2_{1} / a$ space group with four molecules in the unit cell. The molecule is not planar. The triple bond character in the cyano groups is confirmed by N3-C15 = $1.108 \AA$ (N2-C16=1.122 $\AA$ ) bond length and a conjugated double-bond character is shown by the $\mathrm{N} 1-\mathrm{C} 14=1.351 \AA$ bond length. Due to the steric hindrance between the diethylamino and the cyano groups, $-\mathrm{CH}_{2}-\mathrm{CH}_{3}$ units are substantially retained. However, this situation has led to the shortening of the N1-C14 bond. Dihedral angles formed by LSQ-planes between thienyl groups and the phenyl core are $42.1(2)^{\circ}$ and $36.4(2)^{\circ}$. The observed non-planarity of the molecule and the minimization of the steric hindrance, suggests the possibility of extended conjugation in the entire molecule. In the crystal packing of compound 1-II, $\pi-\pi$ stacking is not observed but weak $\mathrm{S}^{\cdots} \pi \pi$ interaction is possible $\left(\mathrm{S}^{\cdots} \mathrm{C}_{\mathrm{g}}{ }^{\mathrm{i}}=\right.$ $3.70 \AA, C_{g}$ is the centroid of phenyl ring, $\left.\mathrm{I}=-1 / 2+\mathrm{x}, 3 / 2-\mathrm{y}, \mathrm{z}\right)$. Moreover, there are $\mathrm{C}-\mathrm{H} \cdots \mathrm{N}$

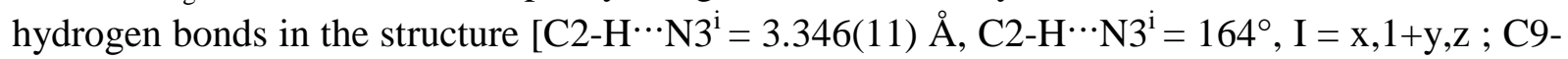
$\mathrm{H}^{\cdots} \mathrm{N}^{3}{ }^{\mathrm{i}}=3.580(11) \AA$, $\left.\mathrm{C} 2-\mathrm{H}^{\cdots} \mathrm{N} 3^{\mathrm{i}}=162^{\circ}, \mathrm{I}=\mathrm{x}+1 / 2,-\mathrm{y}-1 / 2, \mathrm{z}\right]$.

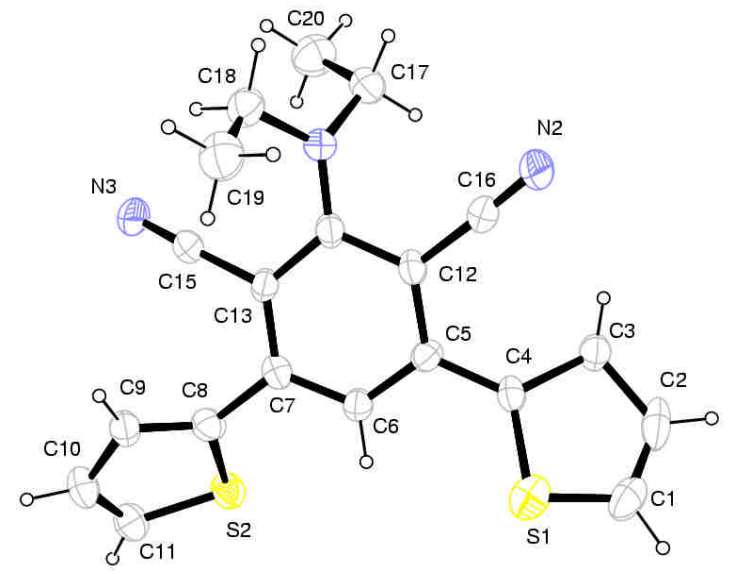

a

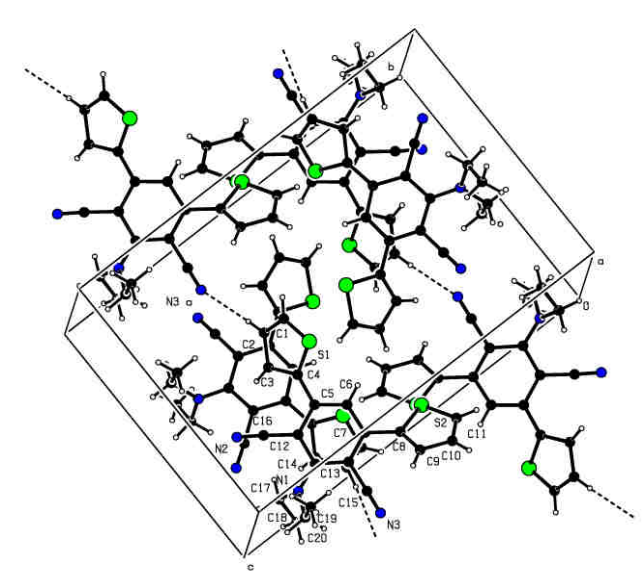

b

Figure 1. (a) ORTEP diagram of compound 1-II. Thermal ellipsoids are drawn at $40 \%$ probability level (b) Crystal packing diagram of compound 1-II. 
After elimination of two cyano groups from 2,6-dicyanoanilines with a base such as sodium hydroxide, potassium hydroxide etc., at high temperature and pressure, the novel aniline derivatives can be obtained. ${ }^{17,22}$ Here, we easily obtained novel type of aniline compound from $\mathbf{1}$, after elimination of two cyano groups using ethanolic solution of sodium hydroxide at high temperature in an autoclave. This approach will be opened a new route for obtaining novel 3,5diaryl/hetarylaniline derivatives from different type of 3,5-disubstituted-2,6-dicyanoanilines, which are difficult to synthesize by other methods (Scheme 6).<smiles>CCNc1c(C#N)c(-c2cccs2)cc(-c2cccs2)c1C#N</smiles><smiles>CCN(CC)c1c(C#N)c(-c2cccs2)cc(-c2cccs2)c1C#N</smiles><smiles></smiles><smiles>CN(C)c1c(C#N)c(-c2cccs2)cc(-c2cccs2)c1C#N</smiles><smiles>O=[N+]([O-])CO</smiles><smiles>Nc1cc(-c2cccs2)cc(-c2cccs2)c1</smiles>

Scheme 6. Mono/dialkylation and decyanization of compound $\mathbf{1 .}$

The synthesized compounds are colored in solid state and in solution. Therefore, UV-vis absorption and fluorescence spectra of the synthesized compounds were measured in DMSO and are presented in Table 3 . They showed wavelength of maximum absorption $\left(\lambda_{\text {max. }}\right)$ in the UV or visible region (393-435 nm). Wavelengths of maximum emission for the compounds $\left(\lambda_{\text {max.em. }}\right)$ (456-563nm) were observed in DMSO at room temperature. They exhibited one absorption and 
emission band in DMSO. The absorption maxima of the compounds 6-13 showed more bathochromic shift than model compound 1 and the compounds 2-5. These bathochromic shifts can be attributed to coumarin chromophore.

Although, the fluorescence quantum yields of compounds $\mathbf{2 - 5}$ were relatively low $(<0.01)$ in DMSO, fluorescence quantum yields for the other compounds (1 and 6-13) were satisfactory according to the reference (Coumarin 153 in ethanol (0.38)). Especially 3,5-diaryl/hetaryl-2,6dicyanoanilines containing (7-N,N-diethylamino)coumarinyl moiety (6-13) showed better fluorescence intensity, quantum yields $\left(\Phi_{\mathrm{fl}}\right)$ and Stokes shift. They have emission even in ambient light (See supplementary data) but the compound 9 bearing nitro substituent on phenyl ring showed the lowest quantum yield because of the strong electron-accepting ability character of the nitro group. However, the compound $\mathbf{1 2}$ bearing methoxy substituent as electron-donor on phenyl ring showed the highest quantum yield.

The effect of the mono/dialkyl substituents on the absorption/emission maxima and their quantum yields can be found in Table 3. The absorption maxima of the dyes (1-I-III), including the alkylamino as electron-donating group showed significant bathochromic shifts according to compound 1. The same trends were observed in emission maxima. The observed bathochromic shifts were due to the increasing intramolecular charge transfer (ICT) from the donor groups (mono and dialkyl groups) to the acceptor groups (cyano). So, the excited state is more stable than the ground state, and absorption band was seen at longer wavelength (Table 3).

Table 3. Photophysical data for compounds (1-13, 1-I-III) in DMSO at room temperature

\begin{tabular}{ccccc}
\hline Compounds & ${ }^{\mathrm{a}} \lambda_{\mathrm{abs}} / \mathrm{nm}\left(\log \varepsilon^{\mathrm{b}}\right)$ & ${ }^{\mathrm{c}} \lambda_{\mathrm{fl}} / \mathrm{nm}$ & ${ }^{\mathrm{d}} \varphi_{\mathrm{fl}}$ & Stokes Shift, $\mathrm{cm}^{-1}$ \\
\hline $\mathbf{1}$ & $396(4.24)$ & 456 & 0.12 & 3322 \\
$\mathbf{2}$ & $401(4.36)$ & 563 & $<0.01$ & 7175 \\
$\mathbf{3}$ & $393(4.38)$ & 547 & $<0.01$ & 7163 \\
$\mathbf{4}$ & $400(4.28)$ & 484 & $<0.01$ & 4338 \\
$\mathbf{5}$ & $394(4.37)$ & 549 & $<0.01$ & 7165 \\
$\mathbf{6}$ & $429(4.43)$ & 553 & 0.13 & 5226 \\
$\mathbf{7}$ & $427(4.50)$ & 531 & 0.17 & 4586 \\
$\mathbf{8}$ & $429(4.58)$ & 538 & 0.27 & 4722 \\
$\mathbf{9}$ & $435(4.58)$ & 513 & $<0.01$ & 3495 \\
$\mathbf{1 0}$ & $426(4.58)$ & 532 & 0.36 & 4677 \\
$\mathbf{1 1}$ & $429(4.60)$ & 542 & 0.26 & 4859 \\
$\mathbf{1 2}$ & $425(4.62)$ & 523 & 0.58 & 4408 \\
$\mathbf{1 3}$ & $429(4.55)$ & 529 & 0.21 & 4406 \\
$\mathbf{1 - I}$ & $406(4.26)$ & 477 & 0.15 & 3666 \\
$\mathbf{1 - I I}$ & $401(3.95)$ & 485 & 0.01 & 4319 \\
$\mathbf{1 - I I I}$ & $409(4.02)$ & 499 & 0.03 & 4409 \\
\hline
\end{tabular}

${ }^{\mathrm{a}}$ Long wavelength absorption maximum, in $\mathrm{nm} ; c=10 \mu \mathrm{M},{ }^{\mathrm{b}} \varepsilon=$ Molar absorption coefficient, $\mathrm{cm}^{-}$ ${ }^{1} \mathrm{M}^{-1}$, ${ }^{\mathrm{c}}$ Fluorescence maximum, in $\mathrm{nm} ; c=0.1 \mu \mathrm{M}$; ${ }^{\mathrm{d}}$ Fluorescence quantum yield relative to Coumarin (0.38) 153 in ethanol. ${ }^{26,27}$ 


\section{Conclusions}

In conclusion, we successfully developed a straightforward, facile and less time consuming method for preparing previously unreported 3,5-disubstituted-2,6-dicyanoanilines, using the cost effective and easily available base, piperidine. We also found that, acetonitrile was an excellent solvent, because for some compounds (1, 6-13), the reaction completed between 10 minutes to 2 hours at room temperature to $80{ }^{\circ} \mathrm{C}$ reaction conditions. The yields were generally moderate to good. The newly synthesized 3,5-diaryl/hetaryl-2,6-dicyanoaniline derivatives are generally fluorescent, thus if there can be a little improvement in our study, it can be a convenient procedure for the synthesis of many fluorescent 3,5-diaryl/hetaryl-2,6-dicyanoanilines that will be attractive for practical applications such as fluorescent sensor or functional dyes.

\section{Experimental Section}

General. Malononitrile, organic and inorganic bases, alkylating agents such as methyl iodide etc. the aldehydes and ketones which transformed to arylidene/hetarylidenemalononitriles purchased from Sigma-Aldrich were used as such, without any further purification. DMF was distilled in $\mathrm{CaH}_{2}$, THF was distilled by reflux with sodium wire in the presence of a small amount of benzophenone under $\mathrm{N}_{2}$. Thin-layer chromatography (TLC) was used for monitoring the domino reactions using precoated silica gel 60 F254 plates. IR spectra were recorded on a Mattson 1000 FT-IR spectrophotometer in $\mathrm{KBr}\left(v\right.$ are in $\left.\mathrm{cm}^{-1}\right) .{ }^{1} \mathrm{H} /{ }^{13} \mathrm{C}$ NMR spectra were recorded on NMR spectrometer Bruker-Spectrospin Avance DPX 300 and 400 Ultra-Shield in DMSO- $d_{6}$. Chemical shifts $(\delta)$ are given in parts per million ( $\mathrm{ppm})$ using the residue solvent peaks as reference relative to TMS. Coupling constants $(J)$ are given in hertz $(\mathrm{Hz})$. Signals are abbreviated as follows: singlet, s; doublet, d; doublet-doublet, dd; triplet, t; multiplet, m. Ultraviolet-visible (UV-vis) absorption spectra were recorded on an Analytikjena Specord 200 Spectrophotometer (Gazi University Department of Chemistry, Turkey) at the wavelength of maximum absorption $\left(\lambda_{\max }\right.$, in $\left.\mathrm{nm}\right)$. Fluorescence spectra were recorded on a HITACHI F-7000 FL Spectrofluorophotometer (Gazi University Department of Chemistry, Turkey). High resolution mass spectra (HRMS) were recorded at Gazi University Faculty of Pharmacy using electron ionization (EI) mass spectrometry (Waters-LCT-Premier-XE-LTOF (TOF-MS) instruments; in $\mathrm{m} / \mathrm{z}$ (rel. \%). The microwave syntheses were carried out in a Milestone Start microwave reaction system. Elementalanalyses were performed using a Leco CHNS-932 at the Ankara University Faculty of Pharmacy. The X-ray data were recorded in the Department of Chemistry, Atatürk University, Erzurum, Turkey. The melting points were measured using Electrothermal IA9200 apparatus. 


\section{Preparation of hetarylethylidenemalononitriles}

The two hetarylethylidenemalononitriles were prepared through the following procedures.

2-(1-(thiophen-2-yl)ethylidene)malononitrile (1a). A solution containing $3.79 \mathrm{~g} \mathrm{(300} \mathrm{mmol)} \mathrm{of}$ the 2-acetylthiophene, $3.30 \mathrm{~g}(500 \mathrm{mmol})$ of malononitrile, $1.20 \mathrm{~g}$ of ammonium acetate, and 24 $\mathrm{mL}$ of glacial acetic acid in $200 \mathrm{~mL}$ of toluene was refluxed with the aid of a Dean-Stark trap for 12 hours after cooling to room temperature. The reaction mixture was concentrated and washed with water $(2 \times 50 \mathrm{~mL})$. It was then dried over anhydrous magnesium sulfate. The solid formed was filtered off and recrystallized using $50 \%$ of ethanol-water (v/v) mixture to obtain a pure compound $\left(3.70 \mathrm{~g}, 77 \%, \mathrm{mp} 85^{\circ} \mathrm{C}\right) .{ }^{28}$

2-[1-(7-( $N, N$-diethylamino-2-oxo-2H-chromen-3-yl)ethylidene)malononitrile (1b). A solution containing $9.40 \mathrm{~g}$ (500 mmol) of 3-acetyl-7-(,$N$-diethylamino)- $2 H$-chromen-2-one, $6.42 \mathrm{~mL}$ $(100 \mathrm{mmol})$ of malononitrile, $2.29 \mathrm{~mL}(400 \mathrm{mmol})$ of acetic acid and $0.77 \mathrm{~g}(100 \mathrm{mmol})$ of ammonium acetate in $50 \mathrm{~mL}$ benzene was refluxed, with the aid of a Dean-Stark trap until the amount of water collected in the trap remained constant for 18 hours. The solvent was evaporated and the remaining yellow viscous oil was precipitated by adding $10 \mathrm{~mL}$ ethanol and filtered off. The crude product was recrystallized from ethanol as yellow needles $(7.67 \mathrm{~g}, 65 \%$, mp 161-162 ${ }^{\circ} \mathrm{C}$, lit. mp 166-168). ${ }^{29}$

The arylethylidenemalononitrile (2-[1-(4-aminophenyl)ethylidene]malononitrile, 1c) was prepared following procedure. A mixture of 4-aminoacetophenone $6.76 \mathrm{~g}$ (50 mmol), malononitrile $3.30 \mathrm{~g}(50 \mathrm{mmol})$, acetic acid $22.9 \mathrm{~mL}(400 \mathrm{mmol})$ and ammoniumacetate $7.70 \mathrm{~g}$ (100 mmol) was added into the reaction system. Subsequently, the reaction vial was capped and the mixture was irradiated $300 \mathrm{~W}$ for $0.5 \mathrm{~min}$. After the time, adding $10 \mathrm{~mL}$ ethanol and filtered off and the filtrate recrystallized from $95 \%$ (v:v) ethanol-water solution yielded light green solid (2.37 g, $92 \% \mathrm{mp} 185{ }^{\circ} \mathrm{C}$ lit. mp 190). ${ }^{30}$

General procedure for the synthesis of hetarylidenemalononitriles. A mixture of hetarylcarbaldehyde $(500 \mathrm{mmol})$ and malononitrile $3.30 \mathrm{~g}(500 \mathrm{mmol})$ in absolute ethanol (100 $\mathrm{mL}$ ) was warmed until complete dissolution. To this solution, five drops of sodium ethoxide solution, prepared by dissolving sodium metal $(0.10 \mathrm{~g})$ in dry ethanol $(10 \mathrm{~mL})$ while shaking, were added. After a vigorous exothermic reaction and boiling of the contents of the flask, a precipitate was instantly formed. The mixture was left to cool, the solid formed was filtered off and recrystallized from ethanol to obtain pure compounds.

General procedure for the synthesis of substituted arylidenemalononitriles. To an appropriate solution of benzaldehyde derivatives $(100 \mathrm{~mol})$ and malononitrile $(100 \mathrm{mmol})$ in ethanol (40 mL), 3-4 drops of an aqueous $10 \mathrm{wt}-\%$ potassium hydroxide was added. The solution was stirred at room temperature for 1 hour, and after that water $(40 \mathrm{~mL})$ was added to the reaction mixture and The crude product obtained was collected by filtration. The crude product was recrystallized from ethanol. 
General procedure for the synthesis of 3,5-disubstituted-2,6-dicyanoaniline derivatives (113).

A solution of arylidene/hetarylidenemalononitriles $(1000 \quad \mathrm{mmol})$, aryl/hetarylethylidenemalononitrile $(1000 \mathrm{mmol})$ and piperidine $(1000 \mathrm{mmol})$ in acetonitrile was stirred at room temperature for compounds 1 and 6-13. For compounds 2-5, it was refluxed for 18 hours. The obtained crude product was collected by filtration and recrystallized from ethanol.

2,6-Dicyano-3,5-di(2-thienyl)aniline (1). Yellow solid, mp 273-274 ${ }^{\circ} \mathrm{C}$; IR $\left(\mathrm{KBr}, v_{\text {max. }}, \mathrm{cm}^{-1}\right)$ : 3469, 3357, 3236, 2211, 1638; ${ }^{1} \mathrm{H}$ NMR (DMSO- $d_{6}, 400 \mathrm{MHz}$ ): $\delta_{\mathrm{H}} 7.86$ (dd, $J 5.01 \mathrm{~Hz}$ and 0.92 $\mathrm{Hz}, 2 \mathrm{H}), 7.74(\mathrm{dd}, J 3.72 \mathrm{~Hz}$ and $0.96 \mathrm{~Hz}, 2 \mathrm{H}), 7.28$ (dd, $J 5.00 \mathrm{~Hz}$ and 3,80 Hz, 2H), 6.99 (s, $1 \mathrm{H}), 6.92$ (s, 2H) ppm. ${ }^{13} \mathrm{C}$ NMR (DMSO- $d_{6}, 100 \mathrm{MHz}$ ): $\delta_{\mathrm{C}} 155.4,142.3,138.4,130.3,129.8$, 128.9, 117.4, 116.6, 92.6 ppm. Anal. calcd. for $\mathrm{C}_{16} \mathrm{H}_{9} \mathrm{~N}_{3} \mathrm{~S}_{2}: \mathrm{C}, 62.52 ; \mathrm{H}, 2.95 ; \mathrm{N}, 13.67 ; \mathrm{S}, 20.86$. found: C, 63.01; H, 3.06; N, 13.69; S, 20.66.

2,6-Dicyano-3-(4-aminophenyl)-5-(2-thienyl)aniline (2). Dark green solid, mp 303-304 ${ }^{\circ} \mathrm{C}$; IR $\left(\mathrm{KBr}, \mathrm{v}_{\text {max }}, \mathrm{cm}^{-1}\right): 3433,3349,3218,3101,2206,1647 ;{ }^{1} \mathrm{H}$ NMR (DMSO- $\left.d_{6}, 300 \mathrm{MHz}\right): \delta_{\mathrm{H}} 7.82$ $(\mathrm{d}, J 5.06 \mathrm{~Hz}, 1 \mathrm{H}), 7.69(\mathrm{dd}, J 2.75 \mathrm{~Hz}$ and $0.90 \mathrm{~Hz}, 1 \mathrm{H}), 7.34(\mathrm{~d}, J 8.45 \mathrm{~Hz}, 2 \mathrm{H}), 7.24(\mathrm{dd}, J$ 4.92 and $3.79 \mathrm{~Hz}, 1 \mathrm{H}), 6.81(\mathrm{~s}, 1 \mathrm{H}), 6.67(\mathrm{~d}, J 8.42 \mathrm{~Hz}, 2 \mathrm{H}), 6.64(\mathrm{~s}, 2 \mathrm{H}), 5.63(\mathrm{~s}, 2 \mathrm{H}) \mathrm{ppm} .{ }^{13} \mathrm{C}$ NMR (DMSO- $\left.d_{6}, 75 \mathrm{MHz}\right): \delta_{\mathrm{C}} 155.2,151.1,150.9,141.5,139.0,130.1,129.8,129.3,128.8$, 124.2, 117.6, 117.1, 117.0, 113.9, 93.3, 91.0 ppm. HRMS (ESI, $\left.\mathrm{CH}_{3} \mathrm{CN}\right)\left(\mathrm{C}_{18} \mathrm{H}_{12} \mathrm{~N}_{4} \mathrm{~S}\right)[\mathrm{M}+\mathrm{H}]^{+}$ found: 317.0849 calcd.: 317.0861 and found: $358.1107\left(\mathrm{C}_{18} \mathrm{H}_{12} \mathrm{~N}_{4} \mathrm{~S}_{-} \mathrm{CH}_{3} \mathrm{CN}\right)\left[\mathrm{M}+\mathrm{CH}_{3} \mathrm{CN}+\mathrm{H}\right]^{+}$ calcd.: 358.1126 .

2,6-Dicyano-3-(4-aminophenyl)-5-(4'-chlorophenyl)aniline (3). Cream colored solid, mp 321$323{ }^{\circ} \mathrm{C}$; IR (KBr, $\left.v_{\text {max. }}, \mathrm{cm}^{-1}\right): 3432,3347,3204,2211,1650 ;{ }^{1} \mathrm{H}$ NMR (DMSO- $\left.d_{6}, 300 \mathrm{MHz}\right): \delta_{\mathrm{H}}$ $7.65(\mathrm{~d}, J 8,66 \mathrm{~Hz}), 7.62(\mathrm{~d}, J 8.64 \mathrm{~Hz}, 2 \mathrm{H}), 7.36(\mathrm{~d}, J 8.54 \mathrm{~Hz}, 2 \mathrm{H}), 6.71(\mathrm{~s}, 1 \mathrm{H}), 6.70(\mathrm{~s}, 2 \mathrm{H})$, $6,65(\mathrm{~d}, J 8,57 \mathrm{~Hz}, 2 \mathrm{H}), 5.62(\mathrm{~s}, 2 \mathrm{H}) \mathrm{ppm} .{ }^{13} \mathrm{C}$ NMR (DMSO- $\left.d_{6}, 75 \mathrm{MHz}\right): \delta_{\mathrm{C}} 154.8,151.0$, $150.9,148.5,137.1,134.7,130.9,130.2,129.1,124.2,118.3,117.1,116.7,113.9,93.6,92.5$ ppm. HRMS (ESI, $\mathrm{CH}_{3} \mathrm{CN}$ ) found: $386.1171\left(\mathrm{C}_{20} \mathrm{H}_{13} \mathrm{~N}_{4} \mathrm{Cl}-\mathrm{CH}_{3} \mathrm{CN}\right)\left[\mathrm{M}+\mathrm{CH}_{3} \mathrm{CN}+\mathrm{H}\right]^{+}$calcd.: 386.1172 .

2,6-Dicyano-3-(4-aminophenyl)-5-(4'-nitrophenyl)aniline (4). Yellow-orange solid, mp 293$294{ }^{\circ} \mathrm{C}$; IR $\left(\mathrm{KBr}, v_{\text {max. }}, \mathrm{cm}^{-1}\right): 3426,3345,3204,2209,1653 ;{ }^{1} \mathrm{H}$ NMR (DMSO-d $\left.6,300 \mathrm{MHz}\right): \delta_{\mathrm{H}}$ $8.35(\mathrm{~d}, J 8.83 \mathrm{~Hz}, 2 \mathrm{H}), 7.90(\mathrm{dd}, J 6.94 \mathrm{~Hz}$ and $1.94 \mathrm{~Hz}, 2 \mathrm{H}), 7.38(\mathrm{~d}, J 8.56 \mathrm{~Hz}, 2 \mathrm{H}), 6.78(\mathrm{~s}$, $2 \mathrm{H}), 6.77(\mathrm{~s}, 1 \mathrm{H}), 6.64(\mathrm{~d}, J 8.59 \mathrm{~Hz}, 2 \mathrm{H}), 5.64(\mathrm{~s}, 2 \mathrm{H}) \mathrm{ppm} .{ }^{13} \mathrm{C}$ NMR (DMSO- $\left.d_{6}, 75 \mathrm{MHz}\right): \delta_{\mathrm{C}}$ 154.8, 151.2, 151.1, 148.3, 147.5, 144.6, 130.6, 130.2, 124.2, 124.1, 118.3, 117.0, 116.4, 113.9, 94.3, 92.4 ppm. HRMS (ESI, $\mathrm{CH}_{3} \mathrm{CN}$ ) found: $397.1414\left(\mathrm{C}_{18} \mathrm{H}_{13} \mathrm{~N}_{5} \mathrm{O}_{2}-\mathrm{CH}_{3} \mathrm{CN}\right)\left[\mathrm{M}+\mathrm{CH}_{3} \mathrm{CN}+\mathrm{H}\right]^{+}$ calcd.: 397.1413 .

2,6-Dicyano-3-(4-aminophenyl)-5-(3-pyrydyl)aniline (5). Light green solid. mp 339-340 ${ }^{\circ} \mathrm{C}$; IR (KBr, $\left.v_{\text {max. }}, \mathrm{cm}^{-1}\right): 3430,3347,3204,2206,1650 ;{ }^{1} \mathrm{H}$ NMR (DMSO- $\left.d_{6}, 300 \mathrm{MHz}\right): \delta_{\mathrm{H}} 8.81$ (d, $J 2.05 \mathrm{~Hz}, 1 \mathrm{H}), 8.70(\mathrm{dd}, J 4.76 \mathrm{~Hz}$ and $1.35 \mathrm{~Hz}, 1 \mathrm{H}), 8.08(\mathrm{dd}, J 6,02 \mathrm{~Hz}$ and $1.69 \mathrm{~Hz}, 1 \mathrm{H}), 7.56$ $(\mathrm{dd}, J 7.81 \mathrm{~Hz}$ and $4.84 \mathrm{~Hz} 1 \mathrm{H}), 7.44(\mathrm{~d}, J 8.49 \mathrm{~Hz}, 2 \mathrm{H}), \delta 6.79(\mathrm{~s}, 1 \mathrm{H}), 6.69(\mathrm{~s}, 2 \mathrm{H}), 6.65(\mathrm{~d}, J$ $8.51 \mathrm{~Hz}, 2 \mathrm{H}), 5.63(\mathrm{~s}, 2 \mathrm{H}) \mathrm{ppm} ;{ }^{13} \mathrm{C} \mathrm{NMR}\left(\mathrm{DMSO}-d_{6}, 75 \mathrm{MHz}\right): \delta_{\mathrm{C}} 154.8,151.2,151.0,150.6$, 
149.2, 146.5, 136.6, 134.1, 130.3, 124.1, 123.9, 118.4, 117.1, 116.1, 113.9, 93.9, 92.7 ppm. HRMS (ESI, $\left.\mathrm{CH}_{3} \mathrm{CN}\right)\left(\mathrm{C}_{19} \mathrm{H}_{13} \mathrm{~N}_{5}\right)[\mathrm{M}+\mathrm{H}]^{+}$found: 312.1245 calcd.: 312.1249 .

2,6-Dicyano-3-(7- $N, N$-diethylamino-2-oxo-2H-chromen-3-yl)-5-(2-thienyl)aniline

(6).

Yellow-orange solid. mp 340-342 ${ }^{\circ} \mathrm{C}$; IR (KBr, $\left.v_{\text {max. }}, \mathrm{cm}^{-1}\right): 3395,3076,2972,2203,1712,1625$; ${ }^{1} \mathrm{H}$ NMR (DMSO- $\left.d_{6}, 400 \mathrm{MHz}\right): \delta_{\mathrm{H}} 8.13(\mathrm{~s}, 1 \mathrm{H}), 7.82(\mathrm{~d}, J 5.02 \mathrm{~Hz}, 1 \mathrm{H}), 7.71(\mathrm{~d}, J 3.62 \mathrm{~Hz}$, $1 \mathrm{H}), 7.56(\mathrm{~d}, J 8.88 \mathrm{~Hz}, 1 \mathrm{H}), 7.28(\mathrm{t}, J 8.79 \mathrm{~Hz}$ and $4.70 \mathrm{~Hz}, 1 \mathrm{H}), 7.01(\mathrm{~s}, 1 \mathrm{H}), 6.84(\mathrm{~s}, 2 \mathrm{H}), 6.80$ (dd, $J 8.82 \mathrm{~Hz}$ and $2.19 \mathrm{~Hz}, 1 \mathrm{H}), 6.61(\mathrm{~d}, J 1.98 \mathrm{~Hz}, 1 \mathrm{H}) 3.47(\mathrm{q}, J 6.83 \mathrm{~Hz}, 4 \mathrm{H}), 1.12$ (t, $J 6.89$ $\mathrm{Hz}, 6 \mathrm{H}$ ) ppm. ${ }^{13} \mathrm{C}$ NMR (DMSO- $d_{6}, 75 \mathrm{MHz}$ ): $\delta_{\mathrm{C}} 145.7,144.9,130.7,129.6,128.9,119.1$, 116.7, 110.0, 96.8, 44.7, 12.8 ppm; HRMS (ESI, $\left.\mathrm{CH}_{3} \mathrm{CN}\right)\left(\mathrm{C}_{25} \mathrm{H}_{20} \mathrm{~N}_{4} \mathrm{O}_{2} \mathrm{~S}\right)[\mathrm{M}+\mathrm{H}]^{+}$found: 441.1369 calcd.: 441.1385 .

2,6-Dicyano-3-(7- $N, N$-diethylamino-2-oxo-2H-chromen-3-yl)-3-(2-furyl)aniline (7). Yelloworange solid. mp 319-321 ${ }^{\circ} \mathrm{C}$; IR (KBr, $\left.v_{\text {max. }}, \mathrm{cm}^{-1}\right)$ : 3386, 3075, 2962, 2200, 1710, 1619; ${ }^{1} \mathrm{H}$ NMR (DMSO- $\left.d_{6}, 400 \mathrm{MHz}\right): \delta_{\mathrm{H}} 8.13(\mathrm{~s}, 1 \mathrm{H}), 8.00(\mathrm{~d}, J 1.58 \mathrm{~Hz}, 1 \mathrm{H}), 7.55(\mathrm{~d}, J 8.93 \mathrm{~Hz}, 1 \mathrm{H})$, 7.40 (d, J $3.53 \mathrm{~Hz}, 1 \mathrm{H}), 7.21(\mathrm{~s}, 1 \mathrm{H}), 6.85-6.78(\mathrm{~m}, 4 \mathrm{H}), 6.60$ (d, $J 1.15 \mathrm{~Hz}, 1 \mathrm{H}), 3.50$ (q, J 6.89 $\mathrm{Hz}, 4 \mathrm{H}$ ), 1.12 (t, $J 6.88 \mathrm{~Hz}, 6 \mathrm{H}) \mathrm{ppm} .{ }^{13} \mathrm{C}$ NMR (DMSO- $d_{6}, 75 \mathrm{MHz}$ ): $\delta_{\mathrm{C}} 159.7,157.0,154.4$, 151.9, 149.2, 145.7, 144.9, 136.6, 130.8, 116.7, 116.7, 116.1, 115.6, 113.4, 109.9, 107.9, 96.8, 95.4, 89.6, 44.7, 12.8 ppm. HRMS (ESI, $\left.\mathrm{CH}_{3} \mathrm{CN}\right)\left(\mathrm{C}_{25} \mathrm{H}_{20} \mathrm{~N}_{4} \mathrm{O}_{3}\right)[\mathrm{M}+\mathrm{H}]^{+}$found: 425.1621 calcd.: 425.1614 .

2,6-Dicyano-3-(4-chlorophenyl)-5-(7- $\mathrm{N}, \mathrm{N}$-diethylamino-2-oxo-2H-1-benzopyran-3-yl)aniline (8). Yellow-orange solid. mp 347-349 ${ }^{\circ} \mathrm{C}$; IR (KBr, v $\left.\max , \mathrm{cm}^{-1}\right): 3402,3075,2971,2207,1706$, 1602; ${ }^{1} \mathrm{H}$ NMR (DMSO- $d_{6}, 400 \mathrm{MHz}$ ): $\delta_{\mathrm{H}} 8.16(\mathrm{~s}, 1 \mathrm{H}), 7.64(\mathrm{dd}, J 8.18$ and $4.09 \mathrm{~Hz}, 4 \mathrm{H}), 7.51$ $(\mathrm{d}, J 8.75 \mathrm{~Hz}, 1 \mathrm{H}), 6.91(\mathrm{~s}, 1 \mathrm{H}), 6.87(\mathrm{~s}, 2 \mathrm{H}), 6.78(\mathrm{~d}, J 7.6 \mathrm{~Hz}, 1 \mathrm{H}), 6.62(\mathrm{~s}, 1 \mathrm{H}), 3.48(\mathrm{q}, J 6.87$ $\mathrm{Hz}, 4 \mathrm{H}$ ), 1.15 (t, $J=6.67 \mathrm{~Hz}, 6 \mathrm{H}$ ) ppm; ${ }^{13} \mathrm{C} \mathrm{NMR}$ (DMSO- $d_{6}, 75 \mathrm{MHz}$ ): $\delta_{\mathrm{C}} 157.0,153.9,151.9$, 148.7, 145.6, 145.0, 136.7, 134.8, 130.9, 130.7, 129.2, 119.6, 116.7, 116.3, 115.9, 110.0, 107.9, 96.8, 96.3, 44.7, 12.8 ppm. HRMS (ESI, $\left.\mathrm{CH}_{3} \mathrm{CN}\right)\left(\mathrm{C}_{27} \mathrm{H}_{21} \mathrm{ClN}_{4} \mathrm{O}_{2}\right)[\mathrm{M}+\mathrm{H}]^{+}$found: 469.1423 calcd.: 469.1431 .

2,6-Dicyano-3-(7- $\mathrm{N}, \mathrm{N}$-diethylamino-2-oxo-2H-1-benzopyran-3-yl)-5-(4-nitrophenyl)aniline

(9). Light brown solid. mp 360-362 ${ }^{\circ} \mathrm{C}$; IR ( KBr, $\left.v_{\text {max. }}, \mathrm{cm}^{-1}\right): 3400,3074,2976,2207,1705$, 1616; ${ }^{1} \mathrm{H}$ NMR (DMSO- $\left.d_{6}, 400 \mathrm{MHz}\right): \delta_{\mathrm{H}} 8.39(\mathrm{~d}, J 8.60 \mathrm{~Hz}, 2 \mathrm{H}), 8.17(\mathrm{~s}, 1 \mathrm{H}), 7.91(\mathrm{~d}, J 8.72$ $\mathrm{Hz}, 2 \mathrm{H}), 7.52$ (d, J $8.92 \mathrm{~Hz}, 1 \mathrm{H}), 6.98(\mathrm{~s}, 1 \mathrm{H}), 6.97$ (s, 2H), 6,79 (d, J $9.31 \mathrm{~Hz}, 1 \mathrm{H}), 6.62(\mathrm{~s}, 1 \mathrm{H})$, 3.48 (q, $J 6.88 \mathrm{~Hz}, 4 \mathrm{H}$ ), $1.15(\mathrm{t}, J 6.88 \mathrm{~Hz}, 6 \mathrm{H}) \mathrm{ppm} ;{ }^{13} \mathrm{C}$ NMR (DMSO- $d_{6}, 75 \mathrm{MHz}$ ): $\delta_{\mathrm{C}} 157.1$, $153.9,151.9,147.7,145.9,145.1,144.2,130.8,130.6,124.3,119.7,116.5,116.1,115.9,110.1$, 107.9, 97.0, 96.8, 44.7, 12.8 ppm. Anal. calcd. for $\mathrm{C}_{27} \mathrm{H}_{21} \mathrm{~N}_{5} \mathrm{O}_{4}$ : C, 67.63; H, 4.41; N, 14.61. found: $\mathrm{C}, 67.31 ; \mathrm{H}, 4.36 ; \mathrm{N}$, 14.52. HRMS (ESI, $\left.\mathrm{CH}_{3} \mathrm{CN}\right)\left(\mathrm{C}_{27} \mathrm{H}_{21} \mathrm{~N}_{5} \mathrm{O}_{4}\right)[\mathrm{M}+\mathrm{H}]^{+}$found: 480.1649 calcd.: 480.1672.

2,6-Dicyano-3-(7- $\mathrm{N}, \mathrm{N}$-diethylamino-2-oxo-2H-1-benzopyran-3-yl)-5-phenylaniline $\quad$ (10). Yellow-orange solid. mp 315-317 ${ }^{\circ} \mathrm{C}$; IR (KBr, $\left.v_{\text {max., }} \mathrm{cm}^{-1}\right): 3401,3075,2971,2206,1704,1619$; ${ }^{1} \mathrm{H}$ NMR (DMSO- $\left.d_{6}, 400 \mathrm{MHz}\right): \delta_{\mathrm{H}} 8.16(\mathrm{~s}, 1 \mathrm{H}), 7.62(\mathrm{~d}, J 5.56 \mathrm{~Hz}, 1 \mathrm{H}), 7.54(\mathrm{~m}, 5 \mathrm{H}), 6.90(\mathrm{~s}$, $1 \mathrm{H}), 6.82(\mathrm{~s}, 2 \mathrm{H}), 6.78(\mathrm{~d}, J 8.79 \mathrm{~Hz}, 1 \mathrm{H}), 6.62(\mathrm{~s}, 1 \mathrm{H}), 3.47(\mathrm{q}, J 6.75 \mathrm{~Hz}, 4 \mathrm{H}), 1.14$ (t, J 6.86 $\mathrm{Hz}, 6 \mathrm{H}) \mathrm{ppm} .{ }^{13} \mathrm{C}$ NMR (DMSO- $\left.d_{6}, 75 \mathrm{MHz}\right): \delta_{\mathrm{C}} 159.7,157.0,153.9,151.8,150.0,145.5$, 
$144.9,137.9,130.7,129.9,129.2,128.9,119.8,116.7,116.5,116.1,110.0,108.0,96.8,95.9$, 94.6, 44.7, 12.8 ppm. HRMS (ESI, $\left.\mathrm{CH}_{3} \mathrm{CN}\right)\left(\mathrm{C}_{27} \mathrm{H}_{22} \mathrm{~N}_{4} \mathrm{O}_{2}\right) \quad[\mathrm{M}+\mathrm{H}]^{+}$found: 435.1808 calcd.: 435.1821 .

2,6-Dicyano-3-(7- $N, N$-diethylamino-2-oxo-2H-1-benzopyran-3-yl)-5-(3-pyrdyl)aniline (11). Yellow solid. mp 327-329 ${ }^{\circ} \mathrm{C}$; IR (KBr, $\left.v_{\text {max. }}, \mathrm{cm}^{-1}\right): 3400,3076,2972,2210,1706,1623 ;{ }^{1} \mathrm{H}$ NMR (DMSO- $\left.d_{6}, 400 \mathrm{MHz}\right): \delta_{\mathrm{H}} 8.81(\mathrm{~d}, J 1.82 \mathrm{~Hz}, 1 \mathrm{H}), 8.72(\mathrm{dd}, J 4.76$ and $3.32 \mathrm{~Hz}, 1 \mathrm{H}), 8.17$ (s, 1H), $8.07(\mathrm{~d}, J 6.15 \mathrm{~Hz}, 1 \mathrm{H}), 7.59(\mathrm{~m}, 1 \mathrm{H}), 7.51(\mathrm{~d}, J 8.93 \mathrm{~Hz}, 1 \mathrm{H}), 6.97(\mathrm{~s}, 1 \mathrm{H}), 6.93(\mathrm{~s}, 2 \mathrm{H})$, $6.78(\mathrm{dd}, J 9.01 \mathrm{~Hz}$ and $2.25 \mathrm{~Hz}, 1 \mathrm{H}), 6.62(\mathrm{~s}, 1 \mathrm{H}), 3.50(\mathrm{q}, J 7.00 \mathrm{~Hz}, 4 \mathrm{H}), 1.15(\mathrm{t}, J 6.91 \mathrm{~Hz}$, $6 \mathrm{H}) \mathrm{ppm} .{ }^{13} \mathrm{C}$ NMR (DMSO- $d_{6}, 75 \mathrm{MHz}$ ): $\delta_{\mathrm{C}} 157.0,153.9,151.9,150.7,149.2,146.7,145.8$, 145.1, 136.6, 133.8, 130.8, 124.0, 119.8, 116.6, 115.9, 110.0, 107.9, 96.8, 94.7, 44.8, 12.8 ppm. HRMS (ESI, $\left.\mathrm{CH}_{3} \mathrm{CN}\right)\left(\mathrm{C}_{26} \mathrm{H}_{22} \mathrm{~N}_{5} \mathrm{O}_{2}\right)[\mathrm{M}+\mathrm{H}]^{+}$found: 436.1753 calcd.: 436.1774

2,6-Dicyano-3-(7-, $\mathrm{N}$-diethylamino-2-oxo-2H-1-benzopyran-3-yl)-5-(4-

methoxyphenyl)aniline (12). Yellow solid. mp 297-299 ${ }^{\circ} \mathrm{C}$; IR (KBr, $\left.v_{\max }, \mathrm{cm}^{-1}\right): 3401,3075$, 2972, 2204, 1706, 1619; ${ }^{1} \mathrm{H}$ NMR (DMSO- $d_{6}, 400 \mathrm{MHz}$ ): $\delta_{\mathrm{H}} 8.12(\mathrm{~s}, 1 \mathrm{H}), 7.56(\mathrm{~d}, J 8.76 \mathrm{~Hz}$, 2H), $7.48(\mathrm{~d}, J 8.92 \mathrm{~Hz}, 1 \mathrm{H}), 7.07$ (d, J $8.80 \mathrm{~Hz}, 2 \mathrm{H}), 6.85$ (s, 1H), 6.77 (s, 1H), 6.76 (s, 2H), $6.69(\mathrm{~d}, J 2.07 \mathrm{~Hz}, 1 \mathrm{H}), 3.81(\mathrm{~s}, 3 \mathrm{H}), 3.45(\mathrm{q}, J 6.81 \mathrm{~Hz}, 4 \mathrm{H}), 1.12(\mathrm{t}, J 6.88 \mathrm{~Hz}, 6 \mathrm{H}) \mathrm{ppm} .{ }^{13} \mathrm{C}$ NMR (DMSO- $\left.d_{6}, 75 \mathrm{MHz}\right): \delta_{\mathrm{C}} 160.7,159.7,156.9,154.1,151.8,149.7,145.3,144.9,130.7$, 130.4, 130.0, 119.6, 116.7, 116.2, 115.9, 114.6, 109.9, 107.9, 96.8, 95.4, 94.4, 55.8, 44.7, 12.8 ppm. HRMS (ESI, $\left.\mathrm{CH}_{3} \mathrm{CN}\right)\left(\mathrm{C}_{28} \mathrm{H}_{24} \mathrm{~N}_{4} \mathrm{O}_{3}\right)[\mathrm{M}+\mathrm{H}]^{+}$found: 465.1941 calcd.: 465.1927.

2,6-Dicyano-3-(4-carboxyphenyl)-5-(7- $\mathrm{N}, \mathrm{N}$-diethylamino-2-oxo-2H-1-benzopyran-3-

yl)aniline (13). Yellow-brown solid. mp 317-319 ${ }^{\circ} \mathrm{C}$; IR (KBr, $\left.v_{\max }, \mathrm{cm}^{-1}\right)$ : 3500-2700, 3401, 2971, 2207, 1705, 1616; ${ }^{1} \mathrm{H}$ NMR (DMSO- $d_{6}, 400 \mathrm{MHz}$ ): $\delta_{\mathrm{H}} 8.16$ (s, 1H), 8.00 (dd, $J 8.28 \mathrm{~Hz}$, $2 \mathrm{H}), 7.57(\mathrm{~d}, J 8.23 \mathrm{~Hz}, 2 \mathrm{H}), 7.51(\mathrm{~d}, J 8.98 \mathrm{~Hz}, 1 \mathrm{H}), 6.91(\mathrm{~s}, 1 \mathrm{H}), 6.82(\mathrm{~s}, 2 \mathrm{H}), 6.77(\mathrm{dd}, J 8.96$ $\mathrm{Hz}$ and $2.24 \mathrm{~Hz}, 1 \mathrm{H}), 6.61(\mathrm{~d}, J$ 2,12 Hz, 1H), $3.46(\mathrm{q}, J 7.06 \mathrm{~Hz}, 4 \mathrm{H}), 1.16(\mathrm{t}, J 6.93 \mathrm{~Hz}, 6 \mathrm{H})$ ppm. ${ }^{13} \mathrm{C}$ NMR (DMSO- $\left.d_{6}, 75 \mathrm{MHz}\right): \delta_{\mathrm{C}} 159.7,157.0,153.9,151.9,149.7,145.5,144.9,130.7$, 129.8, 128.5, 119.7, 116.8, 116.4, 116.0, 110.0, 108.0, 96.8, 96.1, 94.6, 44.7, 23.2, 22.7, 12.8 ppm. HRMS (ESI, $\left.\mathrm{CH}_{3} \mathrm{CN}\right)\left(\mathrm{C}_{28} \mathrm{H}_{22} \mathrm{~N}_{4} \mathrm{O}_{4}\right)[\mathrm{M}+\mathrm{H}]^{+}$found: 479.1706 calcd.: 479.1719.

\section{General alkylation procedure}

In a three necked flask, $5200 \mathrm{mmol} \mathrm{NaH}$ powder (moistened with oil 55-65 \%, $1.20 \mathrm{~g}$ ) and 6.14 g compound 1 (2000 mmol) were dissolved in freshly distilled THF from $\mathrm{CaH}_{2}$ under $\mathrm{N}_{2}$ atmosphere at room temperature. The solution was stirred until its color changed from yellow to dark red overnight. After observing an $\mathrm{H}_{2}$ bubbles, the stirred solution was added, via a syringe, to monoalkylation $20800 \mathrm{mmol}$ alkyl halide (for dialkylation $26000 \mathrm{mmol}$ alkyl halide) under $\mathrm{N}_{2}$ atmosphere. The mixture was stirred for 20 hours at room temperature and after adding $50 \%$ (v:v) $\mathrm{MeOH} / \mathrm{H}_{2} \mathrm{O}$ mixture to solution, a precipitate was formed instantly and filtered off. The crude product was suitable for most synthetic purposes. For further purposes, the alkylated compounds were recrystallized from ethanol.

2,6-Dicyano- $\boldsymbol{N}$-ethyl-3,5-di(2-thienyl)aniline (1-I). The formed solid was collected by filtration and recrystallized from ethanol to give compound as yellow solid in $78 \%$ yield. mp $159-160{ }^{\circ} \mathrm{C}$. 
IR $\left(\mathrm{KBr}, v_{\text {max. }}, \mathrm{cm}^{-1}\right): 3329,3093,2924,2215,1588 ;{ }^{1} \mathrm{H}$ NMR (DMSO- $d_{6}, 400 \mathrm{MHz}$ ): $\delta_{\mathrm{H}} 7.87$ (dd, $J 5.08$ and $1.04 \mathrm{~Hz}, 2 \mathrm{H}), 7.71(\mathrm{dd}, J 3.76$ and $1.02 \mathrm{~Hz}, 2 \mathrm{H}), 7.27$ (dd, $J 5.04$ and $3.74 \mathrm{~Hz}$, 2H), $7.02(\mathrm{~s}, 1 \mathrm{H}), 6.62(\mathrm{~s}, 1 \mathrm{H}), 3.73(\mathrm{~m}, 2 \mathrm{H}), 1.28(\mathrm{t}, J 7.04 \mathrm{~Hz}, 3 \mathrm{H}) \mathrm{ppm} .{ }^{13} \mathrm{C}$ NMR (DMSO- $d_{6}$, $75 \mathrm{MHz}): \delta_{\mathrm{C}} 155.1,143.4,138.3,130.5,130.3,130.1,128.9,118.9,117.4,94.6,47.2,16.2,14.1$ ppm. HRMS (ESI, $\left.\mathrm{CH}_{3} \mathrm{CN}\right)\left(\mathrm{C}_{18} \mathrm{H}_{13} \mathrm{~N}_{3} \mathrm{~S}_{2}\right)[\mathrm{M}+\mathrm{H}]^{+}$found: 336.0626 calcd.: 336.0629 .

2,6-Dicyano- $N, N$-diethyl-3,5-di(2-thienyl)-aniline (1-II). The formed solid was collected by filtration and recrystallized from ethanol to give compound as yellow solid in $74 \%$ yield. mp 133-134 ${ }^{\circ} \mathrm{C}$. IR (KBr, v $\left.v_{\max }, \mathrm{cm}^{-1}\right)$ : 3098, 2924, 2856, 2219, 1566; ${ }^{1} \mathrm{H}$ NMR (DMSO- $d_{6}, 400$ MHz): $\delta_{\mathrm{H}} 7.91(\mathrm{~d}, J 4.93 \mathrm{~Hz}, 2 \mathrm{H}), 7.79(\mathrm{~d}, J 3.56 \mathrm{~Hz}, 2 \mathrm{H}), 7.51(\mathrm{~s}, 1 \mathrm{H}), 7.29$ (dd, $J 4.84 \mathrm{~Hz}$ and $4.04 \mathrm{~Hz}, 2 \mathrm{H}), 3.55$ (q, $J 7.04 \mathrm{~Hz}, 4 \mathrm{H}$ ), $1.13(\mathrm{t}, J 7.04 \mathrm{~Hz}, 6 \mathrm{H}) \mathrm{ppm} .{ }^{13} \mathrm{C}$ NMR (DMSO- $d_{6}, 75$ MHz): $\delta_{\mathrm{C}} 160.5,142.9,137.9,130.8,130.5,129.0,124.4,117.3,107.9,47.2,14.1$ ppm. HRMS (ESI, $\mathrm{CH}_{3} \mathrm{CN}$ ) $\left.\left(\mathrm{C}_{20} \mathrm{H}_{17} \mathrm{~N}_{3} \mathrm{~S}_{2}\right)\right)[\mathrm{M}+\mathrm{H}]^{+}$found: 364.0937 calcd.: 364.0942 .

2,6-Dicyano- $N, N$-dimethyl-3,5-di(2-thienyl)-aniline (1-III). The formed solid was collected by filtration and recrystallized from ethanol to give compound as yellow solid in $73 \%$ yield. mp 219-221 ${ }^{\circ} \mathrm{C}$. IR (KBr, $\left.v_{\text {max. }}, \mathrm{cm}^{-1}\right): 3093,2938,2211,1571 ;{ }^{1} \mathrm{H}$ NMR (DMSO- $\left.d_{6}, 400 \mathrm{MHz}\right): \delta_{\mathrm{H}}$ $7.90(\mathrm{dd}, J 5.06$ and $1.04 \mathrm{~Hz}, 2 \mathrm{H}), 7.76(\mathrm{dd}, J 3.73$ and $1.01 \mathrm{~Hz}, 2 \mathrm{H}), 7.33(\mathrm{~s}, 1 \mathrm{H}), 7.28(\mathrm{dd}, J$ 5.00 and $3.75 \mathrm{~Hz}, 2 \mathrm{H}), 3.25(\mathrm{~s}, 6 \mathrm{H}) \mathrm{ppm} .{ }^{13} \mathrm{C}$ NMR (DMSO- $d_{6}, 75 \mathrm{MHz}$ ): $\delta_{\mathrm{C}} 161.2,143.5$, 138.0, 130.7, 130.5, 129.0, 122.4, 117.8, 103.3, 44.4 ppm. HRMS (ESI, $\left.\mathrm{CH}_{3} \mathrm{CN}\right)\left(\mathrm{C}_{18} \mathrm{H}_{13} \mathrm{~N}_{3} \mathrm{~S}_{2}\right)$ $[\mathrm{M}+\mathrm{H}]^{+}$found: 336.0627 calcd.: 336.0629 .

\section{The elimination of cyano groups}

3,5-di-(2-thienyl)aniline (1-IV). Compound $118.4 \mathrm{~g}(6000 \mathrm{mmol})$ was suspended in a solution of sodium hydroxide $3.0 \mathrm{~g}(75000 \mathrm{mmol})$ in ethanol $(100 \mathrm{~mL})$. The mixture was heated at $220{ }^{\circ} \mathrm{C}$ for 4 hours, without stirring, in $250 \mathrm{~mL}$ autoclave $(2.5 \mathrm{MPa})$. The mixture was coolled in icewater for 2 hours and the precipitated crude amine was filtered off and washed thoroughly with water. Dry amine was neutralized by $10 \%$ hydrochloric acid and the yellow solution was filtered. The crude product was collected by filtration and recrystallized from methanol to give compound as light yellow solid, yield $36 \%$, mp 140-141 ${ }^{\circ} \mathrm{C}$. IR $\left(\mathrm{KBr}, \mathrm{v}_{\text {max. }}, \mathrm{cm}^{-1}\right): 3421,3307$, 3203, 1590; ${ }^{1} \mathrm{H}$ NMR (DMSO- $d_{6}, 400 \mathrm{MHz}$ ): $\delta_{\mathrm{H}} 7.52(\mathrm{dd}, J 5.00 \mathrm{~Hz}$ and 3,84 Hz, 2H), $7.47(\mathrm{~d}, J$ $3.53 \mathrm{~Hz}, 2 \mathrm{H}), 7.13(\mathrm{dd}, J 4.96 \mathrm{~Hz}$ and $3.64 \mathrm{~Hz}, 2 \mathrm{H}), 7.10(\mathrm{~s}, 1 \mathrm{H}), 6.79(\mathrm{~d}, J 1.36 \mathrm{~Hz} 2 \mathrm{H}), 5.43$ (s,

$2 \mathrm{H}) \mathrm{ppm} .{ }^{13} \mathrm{C}$ NMR (DMSO- $\left.d_{6}, 75 \mathrm{MHz}\right): \delta_{\mathrm{C}} 150.3,144.4,135.5,128.7,125.7,123.9,110.9$, 110.7 ppm; HRMS (ESI, $\left.\mathrm{CH}_{3} \mathrm{CN}\right)\left(\mathrm{C}_{14} \mathrm{H}_{11} \mathrm{NS}_{2}\right)[\mathrm{M}+\mathrm{H}]^{+}$found: 258.0402 calcd.: 258.0411. [M+CH $\left.3{ }_{3} \mathrm{CN}+\mathrm{H}\right]^{+}$found: 299.0648 calcd.: 299.0667.

\section{Acknowledgements}

We thank Gazi University for financial support. 


\section{Supporting Information}

The detailed spectroscopic data (Copies of ${ }^{1} \mathrm{H} /{ }^{13} \mathrm{C}$ NMR and HRMS spectra for all new compounds) including crystallographic data (CIF) of all new compounds are available. Single crystal data for compound 1-II (CCDC-979168) has been deposited in the Cambridge Crystallographic Data Center and it can be obtained free of charge via http://www.ccdc.cam.ac.uk/conts/retrieving.html (or from the CCDC, 12 Union Road, Cambridge CB2 1EZ, UK; fax: +44 1223 336033; e-mail: deposit@ccdc.cam.ac.uk). Supplementary data related to this article can be found at http://www.arkat-usa.org/getfile/53355/.

\section{References}

1. Kim, H. N.; Guo, Z. Q.; Zhu, W. H.; Yoon, J. Y.; Tian, H. Chem. Soc. Rev. 2011, 40, 79-93. http://dx.doi.org/10.1039/C0CS00058B

2. Ramulu J.B.; Chanda T.; Chowdhury S.; Nandib G.C.; Singh M. S. RSC Adv. 2013, 3, 53455349. http://dx.doi.org/10.1039/c3ra40450a

3. Borate, H.B.; Kudale, A.S.; Agalave, S.G. Org. Prep. and Procedures Int. 2012, 44, 467-521. http://dx.doi.org/10.1080/00304948.2012.715055

4. Elnagdi, M.H.; Erian A. W. W. Arch. Pharm. 1991, 324, 853-858. http://dx.doi.org/10.1002/ardp.2503241106

5. Hammouda M.; El-Ahl A.S.; El-Toukhee, Y. M.; Metwally, M. A. J. Chem. Res. Synop. 2002, 89-94. http://dx.doi.org/10.3184/030823402103171258

6. El-Sayed, A.M.; Abdel-Ghany, H. J. Heterocyclic Chem. 2000, 37, 1233-1240. http://dx.doi.org/10.1002/jhet.5570370534

7. Rong, L.C; Gao, L.J.; Han, H.X; Jiang, H.; Dai, Y.S.; Tu, S.J. Synth. Commun. 2009, 40, 289-294.

http://dx.doi.org/10.1080/00397910902965970

8. Alvarez-Perez, M.; Marco-Contelles, J. ARKIVOC 2011, (ii), 283-296. http://dx.doi.org/10.3998/ark.5550190.0012.223

9. Chen, X.H.; Zhao, Z.; Liu, Y.; Lu, P.; Wang, Y. Chem. Lett. 2008, 37, 570-571. http://dx.doi.org/10.1246/cl.2008.570

10. Chen, X.; Chen, X.; Zhao, Z.; Lu, P.; Wang, Y. Chin. J. Chem. 2009, 27, 971-977. http://dx.doi.org/10.1002/cjoc.200990165

11. Sofan, M.A.; El-Taweel, F.M; Elagamey, A.G.A. J. Prakt. Chem. 1990, 332, 640-644. http://dx.doi.org/10.1002/prac.19903320508 
12. Hammouda, M.; Zeid, Z.M.A.; Etman, H.A.; Metwally, M.A. Chem. Het. Comp. 2011, 47, $17-21$. http://dx.doi.org/10.1007/s10593-011-0714-3

13. Yi, C.; Blum, C.; Liu, S.X.;Frei, G.;Neels, A.; Stoeckli-Evans, H.; Leutwyler, S.; Decurtins, S.; Tetrahedron 2008, 64, 9437-9441. http://dx.doi.org/10.1016/j.tet.2008.07.084

14. Xu, H.; Li, S.; Liu, H.; Fu, H.; Jiang, Y. Chem. Commun. 2010, 46, 7617-7619. http://dx.doi.org/10.1039/c0cc01544j

15. Moustafa, H. M. Phosphorus, Sulfur, Silicon Relat. Elem. 2001, 175, 129-142. http://dx.doi.org/10.1080/10426500108040261

16. Barthakur, M.G.; Hasib, A.; Gogoi, J.; Boruah, R.C. Steroids 2010, 75, 445-449. http://dx.doi.org/10.1016/j.steroids.2010.02.009

17. Elagamey, A.A.; El-Taweel, F.M.A.; Khodeir, M.N.M. Pharmazie 1992, 47, 418-420.

18. Milart, P.; Wilamowski, J.; Sepiol, J.J.; Tetrahedron 1998, 54, 15643-15656. http://dx.doi.org/10.1016/j.steroids.2010.02.009

19. Bauer, J.D.; Foster, M.S.; Hugdahl, J.D.; Burns, K.L.; May, S.W.; Pollock, S.H.; Cutler, H.G.; Cutler, S.J. Med. Chem. Res. 2007, 16, 119-129. http://dx.doi.org/10.1007/s00044-007-9015-x

20. Wang, J.; Li, Q.; Qi, C.; Liu, Y.; Ge, Z.; Li, R. Org. Biomol. Chem. 2010, 8, 4240-4242. http://dx.doi.org/10.1039/c0ob00089b

21. Shubha J.; Balwant S.K.; Deepika R.; Vasant W. J. Kor. Chem. Soc. 2012, 56, 712-713. http://dx.doi.org/10.5012/jkcs.2012.56.6.712

22. Shaterian, H.R.; Honarmand, M.; Oveisi, A.R. Monatsh. Chem. 2010, 141, 557-560. http://dx.doi.org/10.1007/s00706-010-0302-8

23. Das, P.; Butcher, R.J.; Mukhopadhyay, C. Green Chem. 2012, 14, 1376-1387. http://dx.doi.org/10.1039/c2gc16641k

24. Rong, L.; Han, H.; Yang, F.; Yao, H.; Jiang, H.; Tu, S. Synth. Commun. 2007, 37, 37673772 . http://dx.doi.org/10.1080/00397910701569684

25. Cui, S.L.; Lin, X.F.; Wang, Y.G. J. Org. Chem. 2005, 70, 2866-2869. http://dx.doi.org/10.1021/jo047823h

26. Crosby, G.A; Demas, J.N. J. Phys. Chem. 1971, 75, 991-1024. http://dx.doi.org/10.1021/j100678a001

27. Valeur, B. Molecular Fluorescence, Wiley-VCH Verlag GmbH: Weinheim, 2002.

28. Schneller, S. W.; Moore, D. R. J. Org. Chem. 1975, 40, 1840-1842. http://dx.doi.org/10.1021/jo00900a037

29. Phadtare, S. B.; Jarag, K. J.; Shankarling, G. S. Dyes Pigments 2013, 97, 105-112 http://dx.doi.org/10.1016/j.dyepig.2012.12.001

30. Gazit, A.; Yaish, P.; Gilon, C.; Levitzki, A. J. Med. Chem. 1989, 32, 2344-2352. http://dx.doi.org/10.1021/jm00130a020 